\begin{tabular}{ll}
\hline \hline MINING AND METALLURGY INSTITUTE BOR & ISSN: 2334-8836 \\
& UDK: 622 \\
\hline \hline
\end{tabular}

\title{
KNOWLEDGE AND INNOVATIONS - KEY FACTORS OF DEVELOPMENT AND EMPLOYMENT IN THE MINING COMPANIES
}

\begin{abstract}
The epoch of modern economic development particularly emphasized in the nineties of the twentieth century has a special feature in developed world through development of science and technology whose creator is the man. The intensive model of economic growth, based on the comparative advantages of natural resources and unskilled labor force, is more and more abandoned. Today, this place is taken by a new form of economic creativity that increasingly inaugurates non-material resources: knowledge, innovation, information, quality, standards, time, design, speed, know-how and other. The quality of success of developed economies in the world today is convincingly reflected to the rest of the world, with a desire for rapid and better integration of that part. The level of business success depends primarily on the quality of human resources-central resources available to companies and especially today's mining companies in view of the specificity and nature of the work being carried out. New knowledge about the job and the people are resources of a completely new business philosophy, driver of the new changes and risk bearer, creator of innovation and resource allocation, creator of the new quality and values, creator of jobs and new working places in the mining companies, which is the basic need of our time. That time is the time of our Serbian economy and society that is going through the transition process in the pursuit of European integration.
\end{abstract}

Keywords: human resources, knowledge, education, creativity, innovation, growth and employment

\section{INTRODUCTION}

The economy of our time and economic development are growing fast in very complex and turbulent environment. In analyzing the competitive factors, more prevalent notion is that a man with his values and his position is not only the structure but the basis from which all began and from whom everything depends. Changing the role and functioning of today's mining companies is conditioned by the radical change in the role and importance of their employees. It is necessary to create the new, modern and qualitative human resources, which can provide an efficient realization the objectives of business and development policies of mining companies in the conditions of great economic uncertainty, rapid technological change, dynamic transformation and property relations changes. On the social scene is the civilization whose foundation is in the education and development system, which requires that every person works in a scientific manner in order to participate actively in the social and economic reality, creating the social and personal wealth. The competitive position of any business system, in the global business environment, depends on its flexibility, inventiveness and focus on the

\footnotetext{
* Faculty of Technical Science, Čačak

** Faculty of Technical Sciences, Kosovska Mitrovica
} 
quality of its employees. Knowledge, as the result of development of employees, has become a strategic resource and source of competitive advantage of mining companies and their differentiation in today's economy. The whole process of globalization in all its complexity, which has caused all stronger interdependence of various economy branches and companies on the worldwide basis, leads to actualization the new issues related to human resources and their knowledge as the only creative factor creating new values and profits. Due to the dynamic changes that take place, it can be concluded that all is changeable, but only learning is permanent. This is the most important resource which can have one company, operating system, or individual. The new market positioning requires the growth and development of mining enterprises. Bearer of the growth is competitiveness of companies in this field, and source of growth in them are high- quality human resources, i.e. their knowledge creating the new values.

In development of today's society, the following participate: knowledge, people who know how to apply that knowledge, focus of business systems and whole society to permanent learning and development. Modern developments will be embodied in mining companies with the speed and efficiency that is allowed by development of human resources and speed of adoption the new creative knowledge, skills, habits required by business environment. Development and human labor are categories that complement and condition each other, separated mean nothing. Care and development of human resources can be achieved everywhere where there are employees who need a new and high-quality knowledge by permanent organization of educational process in the business system. The concern about the quality of human resources and their development is reflected through the acquisition of the new innovative knowledge, where the focus of national economy is transferred to the level of business system, which is a feature of the global business economy and global economic development. Business systems, including mining companies, increasingly become the "learning organizations", which are organized, systematic learning and development at every organizational level, in every workplace and everywhere where they become the slightest need .

\section{KNOWLEDGE - RESORCE OF THE NEW CENTURY}

Knowledgebased economy is a modern economy; it is where the value of produced and realized goods and services is created on the basis of applied knowledge which is to say that the exploitation of knowledge play a dominant role in creation of material goods and social wealth. That is why it is said that the world today came into a new era - the era of knowledge. The basic infrastructure elements of prosperity in a knowledge economy are: knowledge as a source of economic development, innovation - as the most valueble source of creating new values and making changes. The era of knowledge lays the foundation of a new economic order and opportunity to create the future that is increasingly reliant on the value of human resources. The new economic era is defined by many scientists, one of them is Peter Drucker, who points out that in the knowledge economy natural resources and labor are no longer the main economic resources, but also the intellectual capital, which is defined as "knowledge that flows through the technology and is in the people." It follows that knowledge is a priority factor of competitiveness. In the global economy, competitiveness in the know-ledge economy becomes tied to the individual businesses, companies and other organizational systems, rather than to the national economy. Globalization as the universal process permeates all aspects of society, it crosses boundaries and establishes the new connections and relationships, creating conditions for faster and more efficient exchange of people, capi 
tal, goods, services, money, information and knowledge. Globalization of knowledge can be understood as the growth, development and exchange of knowledge between different business entities on the global basis.

In the knowledge economy, know-ledge takes on some specifics, and becomes the focus of interest of economic science and practice. It now becomes an organizational knowledge (at the level of business system) and increasingly becomes an essence and bearer of business development and growth, as well as the structure for creation the new knowledge. Doing business in the knowledge economy is characterized by large and sudden changes at all levels and in their sectors and industries; companies becomes larger (the new products, services, increase market); business has an international character; there are the new forms of cooperation between the business system; the fight in the competition becomes sophisticated and takes on new forms; the market becomes more selectively; there are the new requirements of competitiveness.

Knowledge economy as a whole is transformed industrial economy where employees in the industrial economy and all its undertakings are treated as a cost generator. In the knowledge economy, they are considered to be a generator of income and wealth and make valuable economic capital, as it is the case with the mining production today. The power of management, in the industrial economy, depends on the level of organizational hierarchy; in the knowledge economy management power depends on the level of knowledge.

The basic form of profit in the industrial economy was "tangible" - money; in the new economy profit becomes the "intangible", "invisible" - learning, new ideas, new quality, new customers and clients because they are the bearers of economic development. Bottlenecks were money and skills; in the modern economy they are time and knowledge. Era of knowledge brings a whole new perspective on the world economy and inaugurates a brand new manage ment. Man with his knowledge, skills, habits, creativit, motivation and energy is the most important factor of the whole human creativity and the holder of the overall economic development of our time.

\subsection{SPIRITUAL CAPITAL}

Owing to development of human knowledge, the modern world is found in the scientific and technological revolution, which is characterized by an adequate concept of production, exchange and consumption. This shows that the contemporary economic conditions interact with the new forms of organization and management at all levels of business system, branch, national and global economy, where the quality of human resources have a crucial role. The time we live in is, therefore, the time of knowledge, creativity and information. These are the resources of modern economies, which are expected to be able to expand the boundaries of knowledge, but also the productivity and business results.

Without the new creativity and knowledge, restructuring of large systems, resolving redundancies, operation of large mining system, survival of small and medium-sized enterprises, the creation of new jobs is not possible. Creativity and ideas are the most valuable gifts that an individual can possess - the largest social wealth. Therefore, the current economic development focuses on the human side of organizations where human capital is the central to strategic operations. In the current conditions, development the global economy has created an appropriate system of international division of labor. Because the world economic experts rightly claim that functioning of the global economy is a complex system that every day becomes more and more advanced. No national economy and industry can ensure their survival and development today without adequate international affirmation and involvement in the world economy. All events on the world stage and in the global economy as well as all events in the national 
economy and all businesses depend primarily on the knowledge and skills of the human factor. In the world today, most investments are in the labor force as one of basic factors of production, since the economic conditions in the world eco-nomy more and more require increasing knowledge, innovation and motivation to work. The role of human resources has crucial role in today's mining systems that work in quite difficult conditions. In these systems, it should be done more on implementation of the best possible technologies that will facilitate the work of employees and create as safe as possible working conditions. Every part of development the mining system directly depends on development of its employees because it is the only way of use the modern mining technology and modern technical achievements in reaching the business goals and personal interests of any individual. In the world despite all revolutions that have occurred to date (the industrial revolution, scientific-technological revolution, and energy revolution), the "intelligence revolution and profession" is very important. It involves rapid transfer and app-lication of intensive knowledge in deve-lopment of economy and technology. Because nowadays no one and does not question the crucial role of human resources in the entire development. Quality human resources require investment in their development as the "industry knowledge". This is achieved by allocation the funding for human resource development - education and scientific research. Such financial contributions to the world are uneven and different depending on the development of individual countries, and therefore highly skilled and developed human resources are concentrated in the certain parts of the world.

\section{CREATIVITY AND INNOVATION}

Creativity, innovation and knowledge have become the infrastructure for economic creation and further economic progress. The gained experience has proven that overall social and economic development of a country has to bear the entire economically active society (OECD members at their Conference in 1990 proclaimed the "Program of Active Society" as the goal of any national policy). Under this program, all members of the society according to their abilities and mental and physical characteristics should contribute to economic and social development. In order to achieve the set goal, a creative climate in society should be created. Today, it is equated with political freedom, their democracy and equality before the law and other. To create a creative climate, it needs to have primarily fair and humane relationship between: the state - individual, organization - individual, group - individual and individual - individual. The most important relationship, that makes individual act creative and motivated for creativity, is the ratio of state - individual, where the individual feels belonging and freedom. The undisputed fact in the world today is the fastest growing company and those industries that use well the creative individuals who have always been the engine of mankind growth. Therefore, the issue has been raised today, both at the national level or at the level of business system, how to identify, develop and use creativity of individuals or groups who have the greatest creative abilities.

Creativity is a set of capabilities that enable an individual in certain circumstances to create the new products, expand the new ideas in order to progress the wider community. The basic philosophy of human resource management in this case is to treat an individual as a mature person, bearer of ideas and creativity, productivity and quality. Creative individuals are characterized by: intellectual curiosity, sensitivity to problems at the time, mental openness, restless mind, activity, often dissatisfaction, the ability to see connections between various facts, the tendency to solve problems, rather than to study the phenomena, high intelligence and hunger for creativity. Creativity is caused by the creative climate that should be developed in operating systems, which is reflected in a 
democratic atmosphere, different types of awards, commendations, and other benefits. Here, in fact, business and healthy creative environment worthy of the man and the treatment of employees as associates is required. In order to develop creativity as an resource of innovation in mining systems, it is necessary to create the motivation for its development and creativity because this area of work is one of the most difficult areas of human creativity, that is, the riskiest area. If employees in these systems are considered to be carriers of development and therefore are adequately rewarded and, if it is invested in their development and creativity, the mining systems will develop and the all results will be more productive.

Creativity cannot be expressed by command, under pressure, conditions and under adverse circumstances. In contrast, the humane conditions consistent with human nature should be created in mining systems for activation and expression skills, knowledge, intellect, talent and their transferring to the material and social goods, which is the goal of the individual and mining system. Here is the important question of how the objectives of the business system will be aligned with the goals and needs of the individual and its employees. Individual will be creative at work until he/she has a corresponding benefit in return, compensation, reward or recognition in response to their contribution and will remain on it until he/she is able to prove himself professionally and as such achieves individual and organizational interests. Type of creativity that will be present in an individual (innovative, productive, inventive or emergent top - revolutionary creativity), is caused by a number of specific characteristics, abilities and personality traits as well as by characteristics of these business systems and the nature of work in them.

\section{INNOVATION - THE WAY TO THE NEW JOBS}

Each operating system has a built in system of human resource management.
Regardless of whether the system is developed and a comprehensive or not, whether it is functional or not, it is an inseparable segment of the business system , because it works through purposeful actions of people. This appropriateness, that is, human labor has to be shaped and enabled, started and appropriate people should be involved. How the management of human resources will be organized at the level of systemic presence of the management of this key resource, depend on a number of factors. The essence of human resource management in mining systems refers to the "management of employment and development of people" and "management of people engagement" when they have been formally employed.

Production development of mining systems is determined by condition of the human factors of production. The level of employment in the mining enterprises is seen as a significant factor in the economic growth of these systems. In addition to the level of employment for themselves, an important factor that affects the efficiency and effectiveness of the mining system is productive employment, which goes beyond the unproductive employment, and extensive management problem.

Unproductive employment grows, and productive employment decreases if the business system employs an increasing number of people above the level required by the current volume of its production. This often happens due to introduction the new technology and new technological procedure in which highly productive machines, robots and other automated systems replace a large number of previously employed people, but this is how it comes to redundant that remains formally employed in the business system. Similar character is with redundancies resulting from more rational organization of work, changes in productive organization of business systems, as well as reduction the physical volume of production. Unproductive employment in our environment often 
has been developed and grown for mass employment motivated not by productive but social and political reasons (characteristic of the eighties of the last century). Extensive employment may occur when the business system is not in a position to adequately recruit candidates from internal sources for vacant or new positions and is then sent to an external source. This form of extensive employment is conditioned not only by subjective causes, but often by insufficient possibilities for engagement the adequate workers on one hand, and on the other avoiding or reducing the possibility for downsizing or retraining the existing employees. Here the problem is that the structure of knowledge of employees in business systems, as well as of those that are available on the job market, more and more is behind the required knowledge structure. In these situations, business systems are in a state of unproductive employment and labor market is in situation of structural unemployment. Although, it is characteristic for our state of the eighties that problem is present in a somewhat milder varieties today, what is a big problem. This is usually a problem on the global scale, which is unequally expressed in different parts of the world. The key to solve this important problem can be found in dynamic restructuring of knowledge through various forms of professional development and training in both business systems and labor markets, and what is their obligation and duty. The problem of the world economy, and our in it, is that in the postwar years hundreds of different occupations disappeared, giving way to hundreds of new jobs that did not find their proper application, all to the detriment of many basic jobs such as miners, metal worker, builders and other basic jobs. This indicates that there is a growing disharmony between the production and education system. Education reforms even in many developed countries did not give the expected results and inflexibility of educa tion acted as a factor slowing down technical and technological development, as it is the case with us. At present time, the situation is much better, but not sufficient. High speed and degree of development of modern science and new technologies as well as increasing use of micro - processors and biotechnology, robotics and other numerous business and economic activities, increasing emphasis is placed on the rigid educational system in order to adequately restructure and form a quality profile.

These situations increasingly point out to the new shapes and forms of non-formal education and development, as well as selfeducation which in recent years has received a form of permanent process. Systematic education and additional training for new occupations remain developing the ultimate task in our country.

\section{TRANSITION AND EMPLOYMENT}

The transition process in which there is Serbia, the transformation of social ownership in different forms of ownership, participation in global trade flows, foreign investment in the domestic economy and everything else requires a radical change in the attitude toward human resources, in the way of their education, development, use and management. Ways to raise productive employment are different in different countries and different industries. The general trend in developing countries, where our country is, is attractive to the foreign capital, completion of transition process of ownership, transformation of large business systems in more small and medium-sized with integral process of educational restructuring of knowledge, abilities and skills of both those who are employed and those being educated for employment.

Rapid economic development requires the new and modern knowledge which must be in accordance with the innovations in the region because it is the only 
requirement, not only for reducing the gap between developed and underdeveloped, but also for survival in today's global marketplace. That is why today's global economy is called the "knowledge economy", because the resource contained in knowledge becomes the basis of production and source of wealth. The biggest flaw in Serbian development is related to the human resources, and to inadequate education and inadequate training of employees, both at micro and macro level, inadequate care of this factor, as well as inadequate human resources management .Such state of key resource is the base for insufficient competitiveness of the local economy, as well as one of its deep, structural caused problems. To get out of those situations in which is the entire Serbian economy, including the mining production, it is necessary to turn the scientific and educational system toward the production and diffusion of intensive required knowledge and toward flexible use and benefit of knowledge and continuous improvement. Business systems as the main economic actors need to develop and act on the principles of the new business philosophy that is conditioned by radical changes in the role and importance of human factor in them. Today, more and more, the entirely new organizational forms constitute, which in the global economy on the basis of principles of entrepreneurship, provide intensification of all business resources, especially human resources, as well as the efficient management and use of the same for larger business results and increased market competitiveness.

\section{CONCLUSION}

The changes are characteristic of the twenty-first century. They are deep and fast covering all areas of work and life. Changes in the environment have a crucial impact on shaping the future goals of economic entities, giving them a new feature and a new approach, which is a strategic approach. The strategic approach is the new, modern and necessary access to the mining systems management, which implies a continuous process of adaptation to variable operating system environment. This leads to the emergence of strategic management, and so human resources have become the main strategist and the holder of such management. By focusing on human resources and their development, the business systems become means of change and creators of their own destiny. Knowledge as the result of development of employees has become the strategic resource and source of competitive advantage and differentiation in today's economy. Investment in knowledge become the most lucrative investments in social capital, and the only way out of the economic recession in which the Serbian economy and society is. Only the new and high quality knowledge and creative people can create the new jobs, and thus the new processes and new values making the source of wealth and social well-being. The current level of competitiveness of Serbian economy and mining company does not provide the international positioning. For Serbian overall situation, in which the entire society is found, there is no easy or quick way to remove barriers of large determinant of uncompetitive. In all obstacles, it needs to work intensively, studiously, professionally, with the help of foreign accumulation for which an appropriate business environment should be created. The new environment and new social laws are infrastructure for new economic activity, which requires development of education system and quality of human resources through large investments in development of innovation and new businesses with respect and integration into the global standards of good management.

\section{REFERENCES}

[1] Grozdanić R.: Entrepreneurship, Facu1ty of Technical Science, Čačak, 2005;

[2] Senge P.: The Fifth Discipline, Mosaic Books, Zagreb, 2001; 
[3] Drucker P.: Managing in the New Society, Adizes, Novi Sad, 2005;

[4] Drucker P.: Innovation and Entrepreneurship, Globus, Zagreb, 1992;

[5] Torrington D.: Human Resource Management, Data Status, Belgrade, 2002;

[6] Janićijević N.: Organizational Behavior, Data Status, Belgrade, 2009;

[7] Ćamilović S., Vidojević V.: Fundamentals of Human Resource Management, Tekon, Belgrade, 2007;
[8] Bahtijarević - Siber, F.: Human Potential Management, Zagreb, 1999;

[9] Radovanović V.: Human Resource Management, MST Gajic, Belgrade, 2009;

[10] Radovanović V.: Organizational Behavior, MST Gajic, Belgrade, 2011;

[11] Stephen P. R.: Organizational Behavior, the second edition, Prentice Hall, USA 2003;

[12] Vujic D.: Human Resource Management and Quality, Center for Applied Psychology, Belgrade 2003. 


\begin{tabular}{ll}
\hline \hline INSTITUT ZA RUDARSTVO I METALURGIJU BOR & ISSN: 2334-8836 \\
& UDK: 622 \\
\hline \hline
\end{tabular}

Vladimir Radovanović, Ljiljana Savic ${ }^{* *}$

\title{
ZNANJE I INOVACIJE KLJUČNI FAKTORI RAZVOJA I ZAPOŠLJAVANJA U RUDARSKIM PREDUZEĆIMA
}

\begin{abstract}
Izvod
Epoha modernog ekonomskog razvoja, posebno potencirana devedesetih godina dvadesetog veka, $u$ razvijenom delu sveta ima posebno obeležje u razvoju nauke i tehnologije čiji je kreator i tvorac čovek. Sve više se napušta intenzivni model ekonomskog rasta zasnovan na komparativnoj prednosti prirodnih resursa i nisko kvalifikovane radne snage. Danas to mesto zauzima jedan novi oblik ekonomskog stvaralaštva koji sve više inauguriše nematerijalne resurse: znanje, inovacije, informacije, kvalitet, standarde, vreme, dizajn, brzinu, know-how i drugo. Kvalitet uspeha razvijenih ekonomija sveta danas se sve ubedljivije reflektuje na ostatak sveta, sa željom na što brže i kvalitetnije integrisanje tog dela. Stepen poslovnog uspeha prvenstveno zavisi od kvaliteta ljudskih resursa-centralnog resursa sa kojima raspolažu privredna društva a naročito današnja rudarska preduzeća sobzirom na specifičnost i prirodu poslova koji se u njima obavljaju. Nova znanja o poslu i ljudima su agens potpuno nove poslovne filozofije, pokretač novih promena i nosilac rizika, tvorac inovacija i alokacije resursa, tvorac novih $k v a l i t e t a$ i vrtednosti, stvaralac poslova $i$ novih radnih mesta u rudarskim preduzećima, što je nasušna potreba današnjeg vremena. To vreme je vreme naše srpske privrede i društva u celini koje prolazi kroz. tranzicioni proces u težnji ka evropskim integracijama.
\end{abstract}

Ključne reči: ljudski resursi, znanje, obrazovanje, kreativnost, inovacije, razvoj, zapošljavanje.

\section{UVOD}

Ekonomija današnjeg doba i privredni razvoj nalaze se u brzom usponu i veoma složenom i turbulentnom okruženju. U analizi njihovih konkurentnih faktora, sve više preovladava shvatanje da čovek sa svojim vrednostima i njegov položaj nije samo struktura već osnov od koga sve počinje i od koga sve zavisi. Promena uloge i načina funkcionisanja današnjih rudarskih preduzeća uslovljena je radikalnom promenom uloge i značaja zaposlenih u njima. Potrebno je stvoriti nove, savremene i kvalitetnije ljudske resurse, koji mogu da obezbede efikasno ostvarivanje ciljeva poslovne i razvojne politike rudarskih preduzeća i to u uslovima velike privredne neizvesnosti, brzih tehnoloških promena, dinamične transformacije i promene svojinskih odnosa. Na društvenu scenu stupa civilizacija čiji se osnov nalazi u obrazovnom i razvojnom sistemu, koji zahteva da svaki čovek na naučni način radi, kako bi aktivno učestvovao u društvenoj i privrednoj stvarnosti, stvarajući drušveno i lično bogatstvo. Konkurentna pozicija svakog poslovnog sistema, u globalnom poslovnom okruženju, zavisi od njegove fleksibilnosti, invetivnosti i fokusa na kvalitet svojih zaposlenih. Znanje kao rezultat razvoja zaposlenih, postalo je strateški resurs i

\footnotetext{
* Fakultet tehničkih nauka Čačak

*** Fakultet tehničkih nauka Kosovska Mitrovica
} 
izvorište konkurentne prednosti rudarskih preduzeća i njihove diferencijacije u savremenoj ekonomiji. Čitav proces globalizacije u celoj svojoj kompleksnosti, koji je uslovio sve čvršću međuzavisnost različitih ekonomija, grana i privrednih subjekata na svetskom nivou, dovodi do aktuelizacije novih pitanja $u$ vezi sa ljudskim resursima i njihovim znanjima kao jedinim kreativnim faktorom stvaranja nove vrednosti i profita. S obzirom na dinamičnost i promene koje se dešavaju, može se zaključiti da je sve promenljivo samo je sticanje znanja stalno. To je najvažniji resurs kojim može da raspolaže jedno društvo, poslovni sistem ili pojedinac. Novo pozicioniranje na tržištu zahteva rast i razvoj rudarskih preduzeća. Nosilac rasta je konkurentnost preduzeća u ovoj delatnosti, a izvor rasta u njima su kvalitetni ljudski resursi tj. njihova znanja koja stvaraju nove vrednosti

U razvoju današnjeg društva učestvuju: znanje, ljudi koji znaju kako to znanje da primene, usmerenost poslovnih sistema i čitavog društva na permanentno učenje i razvoj. Savremena dostignuća biće opredmećena $\mathrm{u}$ rudarskim preduzećima onom brzinom i efikasnošću koju dopušta razvijenost ljudskih resursa i brzina usvajanja novih kreativnih znanja, veština, navika, sposobnosti koje zahteva poslovno okruženje. Razvoj i ljudski rad su kategorije koje se dopunjuju i uslovljavaju, a odvojeno ne znače ništa. Razvoj i briga za ljudske resurse može se postići svuda tamo gde se nalaze zaposleni kojima su potrebna nova i kvalitetna znanja, i to stalnim organizovanjem obrazovnog procesa $\mathrm{u}$ poslovnom sistemu. Ovde se briga o kvalitetu ljudskih resursa $\mathrm{i}$ njihovom razvoju ogleda preko sticanja novih inovativnih znanja, gde se fokus sa nacionalnih ekonomija prenosi na nivo poslovnog sistema, što je odlika globalne poslovne ekomije i globalnog ekonomskog razvoja. Poslovni sistemi, a među njima i rudarska preduzeća, sve više postaju "organizacije koje uče", što podrazumeva organizovano, sistematsko učenje i razvoj na svakom organizacionom nivou, na svakom radnom mestu i svuda tamo gde se za njim ukaže i najmanja potreba.

\section{ZNANJE- RESURS NOVOG VEKA}

Ekonomija zasnovana na znanju je savremena ekonomija, u njoj je vrednost ukupno proizvedenih $\mathrm{i}$ realizovanih roba $\mathrm{i}$ usluga stvorena na bazi primenjenog znanja, što će reći da eksploatacija znanja igra dominantnu ulogu u stvaranju materijalnih dobara i društvenog bogatstva. Zato se i kaže da je današnji svet ušao u jedno novo doba doba znanja. Osnovni ifrastrukturni elementi za prosperitet u ekonomiji znanja su: znanje kao izvor ekonomskog razvoja, inovacijekao najvredniji izvor stvaranja nove vrednosti i stvaranje promena. Doba znanja postavlja temelje novog ekonomskog poretka i šansu kreiranja nove budućnosti, koja se sve više oslanja na vrednost ljudskog potencijala. Novo ekonomsko doba definišu mnogi naučnici, jedan od njih je Piter Drucker koji ističe da u ekonomiji znanja prirodni resursi i rad nisu više osnovni ekonomski resursi, već je to intelektualni kapital koji definiše kao ,znanje koje teče kroz tehnologiju i nalazi se u ljudima“. Iz navedenog proizilazi da je znanje prioritetni faktor konkurentnosti. U globalnom poslovanju u ekonomiji znanja konkurentnost postaje vezana za pojedinačne privredne subjekte, preduzeća i druge organizacione sisteme, a sve manje za nacionalne ekonomije. Globalizacija kao univerzalni proces prožima sve aspekte društva, ona ruši granice i uspostavlja nove veze i odnose stvarajući uslove za bržu i efikasniju razmenu ljudi, kapitala, roba, usluga, novca, informacija i znanja. Globalizaciju znanja možemo razumeti kao rast, razvoj i razmenu znanja između različitih ekonomskih subjekata na globalnoj osnovi.

U ekonomiji znanja, znanje poprima neke specifičnosti i postaje fokus interesovanja ekonomske nauke i prakse. Ono danas postaje organizacijsko znanje (na nivou 
poslovnog sistema) i sve više postaje suština i nosilac poslovnog razvoja i rasta, kao i struktura za stvaranje novih znanja. Poslovanje u ekonomiji znanja karakteriše se velikim i naglim promenama na svim nivoima i u svom sektorima i granama, privredni subjekti postaju veći (novi proizvodi, usluge, povećanje tržišta), poslovanje ima internacionalni karakter, niču novi oblici saradnje između poslovnih sistema, borba u konkurenciji postaje sofisticirana i poprima nove oblike, tržište postaje sve probirljivije, nastaju novi zahtevi konkurentnosti.

Ekonomija znanja u celini predstavlja transformisanu industrijsku ekonomiju gde se zaposleni u industrijskoj ekonomiji i svim njenim privrednim subjektima tretirani generatorom troška. U ekonomiji znanja oni se smatraju generatorom prihoda i bogatstva i čine najvredniji ekonomski kapital, što je slučaj i sa rudarskom proizvodnjom danas. Moć menadžmenta, u industrijskoj ekonomiji, zavisi od nivoa u organizacionoj hijerarhiji, u ekonomiji znanja moć menadžmenta zavisi od nivoa znanja.

Osnovni oblik dobiti u industrijskoj ekonomiji bio je ,, opipljiv“ - novac, u novoj ekonomiji dobit postaje „neopipljiv“, „,nevidljiv“- učenje, nove ideje, novi kvaliteti, novi kupci i klijenti, jer su to nosioci privrednog razvoja. Uska grla bila su novac i veštine $\mathrm{u}$ modernoj ekonomiji to postaju vreme i znanje. Era znanja donosi potpuno nove poglede na svet ekonomije i inauguriše potpuno novi menadžment. Čovek sa svojim znanjima, sposobnostima, navikama, veštinama, kreativnošću, motivacijom i energijom najbitniji je faktor celokupnog ljudskog stvaralaštva i nosilac celokupnog privrednog razvoja današnjeg doba.

\subsection{DUHOVNI KAPITAL}

Zahvaljujići razvoju ljudskih znanja, savremeni svet se našao u naučno-tehnološkoj revoluciji koju karakteriše adekvatan koncept proizvodnje, razmene i potrošnje. To pokazuje da su savremeni uslovi privređivanja $\mathrm{u}$ interakciji sa novim oblicima organizovanja i menadžmenta na svim nivoima od poslovnog sistema, granske, nacionalne do svetske privrede, gde presudnu ulogu imaju kvalitetni ljudski resursi. Vreme u kome živimo je, dakle, vreme znanja, kreativnosti i informacija. To su resursi savremene ekonomije od kojih se očekuje da mogu proširiti granice saznanja, ali i produktivnosti i poslovnih rezultata.

Bez novih kreativnosti i znanja nije moguće restruktuiranje velikih sistema, rešavanje viškova zaposlenih, funkcionisanje velikih rudarskih sistema, opstanka malih i srednjih preduzeća, otvaranje novih radnih mesta. Kreativnost i ideje su najvredniji darovi koje pojedinac može posedovati, najveće društveno bogatstvo. Stoga se današnji ekonomski razvoj fokusira na ljudsku stranu organizacije gde ljudski kapital zauzima centralno mesto u strateškom poslovanju. U današnjim uslovima razvoja globalizacije svetske privrede stvoren je i odgovarajući sistem međunarodne podele rada. Zato svetski ekonomski eksperti s punim pravom tvrde da funkcionisanje svetske privrede predstavlja najsloženiji sistem koji se svakog dana sve više razvija i usavršava. Nijedna nacionalna ekonomija i privredna grana, danas ne može obezbediti svoj opstanak i razvoj bez adekvatne međunarodne afirmacije i uključivanja u svetske privredne tokove. Sva dešavanja na svetskoj sceni i u globalnoj ekonomiji kao i sva dešavanja u nacionalnim ekonomijama i svim privrednim subjektima zavise prvenstveno od znanja i sposobnosti ljudskog faktora. Danas se u svetu od osnovnih faktora proizvodnje najviše ulaže $\mathrm{u}$ radnu snagu, pošto uslovi privređivanja $\mathrm{u}$ svetskoj ekonomiji sve više zahtevaju sve veća znanja, inovacije i motive za rad. Uloga ljudskog resursa ima presudnu ulogu u današnjim rudarskim sistemima koji rade u dosta teškim uslovima. U ovim sistemima treba sve više raditi na primeni što kvalitetnije tehnologije kojom će se olakšati rad zaposlenih i stvoriti što bezbedniji uslovi za 
rad. Svaki deo razvoja rudarskih sistema u direktnoj je zavisnosti od razvijenosti njegovih zaposlenih, jer je to jedini put $\mathrm{i}$ način korišćenja savremene rudarske tehnologije i savremenih tehničkih dostignuća u ostvarenju poslovnih ciljeva i ličnih interesa svakog pojedinca. U svetu pored svih revolucija koje su se do danas dešavale (industrijska revolucija, naučno-tehnološka revolucija, energetska revolucija), veoma je bitna "revolucija inteligencije i profesije. "Ona podrazumeva ubrzan transfer i primenu intenzivnih znanja $u$ razvoju ekonomije i tehnologije. Zato danas niko više i ne dovodi u pitanje ključnu ulogu ljudskih resursa u celokupnom razvoju. Kvalitetni ljudski resursi zahtevaju investiciona ulaganja u njihov razvoj kao "industriju znanja". To se postiže izdvajanjem finansijskih sredstava za razvoj ljudskih resursa - za obrazovanje i za naučno istraživački rad. Ovakva finansijska izdvajanja u svetu su neujednačena i različita što zavisi od razvijenosti pojedinih zemalja, pa su zato visoka znanja i razvijeni ljudski resursi koncentrisani u određenim delovima sveta.

\section{KREATIVNOST I INOVATIVNOST}

Kretivnost, inovativnost i znanje postali su infrastruktura za ekonomsko stvaralaštvo i dalji ekonomski napredak. Dosadašnje iskustvo dokazalo je da ukupni društveni i ekonomski razvoj jedne zemlje mora da nosi celo radno aktivno društvo, (članice OECDa su na svojoj konferenciji 1990. godine proklamovale "program aktivnog društva" kao cilj svake nacionalne politike). Po tom programu svi članovi društva prema svojim sposobnostima i psihofizičkim osobinama treba da doprinesu ekonomskom i društvenom razvoju. Da bi se postavljeni cilj postigao treba stvoriti stvaralačku klimu u društvu. Danas se to izjednačava sa političkim slobodama, demokratičnošću i jednakošću ljudi pred zakonom i dr. Za stvaranje stvaralačke klime potreban je prvenstveno korektan i human odnos na relaciji: država - pojedinac, organizacijapojedinac, grupa - pojedinac kao i pojedinac - pojedinac. Najbitniji odnos, kako bi pojedinac stvaralački delovao i bio motivisan za kreativnost, je odnos država-pojedinac, gde pojedinac oseća pripadnost i slobodu. Neosporna činjenica danas u svetu je da se najbrže razvijaju ona društva i one privredne grane koje najbolje koriste kretivne pojedince, koji su oduvek bili pokretači razvoja čovečanstva. Zato je danas usledilo pitanje, kako na nacionalnom nivou ili na nivou poslovnog sistema prepoznati, razvijati i koristiti kreativnost pojedinaca ili grupa koji imaju najveće stvaralačke sposobnosti.

Kreativnost je skup onih sposobnosti koje pojedincu omogućavaju da u određenim okolnostima stvara nove proizvode, širi nove ideje u cilju progresa šire društvene zajednice. Osnovna filozofija menadžmenta ljudskih resursa u ovom slučaju je tretiranje pojedinca kao sveukupne, zrele ličnosti, nosioca ideja i kreativnosti, produktivnosti i kvaliteta. Kreativnog pojedinca karakteriše: intelektualna radoznalost, osetljivost za probleme $\mathrm{u}$ datom trenutku, mentalna otvorenost, nemiran um, aktivan, često nezadovoljan, sposobnost sagledavanja veze između najrazličitijih činjenica, sklonost ka rešavanju problema, umesto ka proučavanju pojava, visoka inteligencija i glad za stvaralaštvom. Kreativnost je uslovljena stvaralačkom klimom koja treba da bude razvijena u poslovnim sistemima, koja se ogleda kroz demokratsku atmosferu, kroz različite vidove nagrada, pohvala, beneficija i dr. Ovde je, u stvari, potrebna poslovna i zdrava stvaralačka sredina dostojna čoveka i tretman zaposlenih kao saradnika. Da bi se razvijala kreativnost kao agens inovacija u rudarskim sistemima, nužno je stvoriti motiv više za njen razvoj i stvaralaštvo iz razloga što ova oblast rada spada u najteže oblasti ljudskog stvaralašta tj u najrizišnije oblasti. Ukoliko se u ovakvim sistemima zaposleni smatraju nosiocem razvoja i shodno tome se nagrađuju i u njihov razvoj i kreativnost se adekvatno ulažu finansijska sredstva rezul- 
tati neće izostati, već će se, naprotiv, rudarski sistemi razvijati a njihovi rezultati biti sve produktivniji.

Kreativnost se ne može izraziti naredbom, pod pritiskom, uslovljavanjem i u nepovoljnim okolnostima. Nasuprot tome, $\mathrm{u}$ rudarskim sistemima treba stvarati humane uslove usklađene sa prirodom čoveka radi aktiviranja i ispoljavanja sposobnosti, znanja, intelekta, talenta i njihovo pretakanje u materijalna i društvena dobra što je cilj kako pojedinca tako i rudarskih sistema. Ovde je bitno pitanje koliko će ciljevi poslovnog sistema biti usklađeni sa ciljevima i potrebama pojedinaca i zaposlenih $u$ njoj. Zaposleni pojedinac biće kreativan $u$ svom poslu sve dok za uzvrat ima odgovarajuću korist, nadoknadu, nagradu ili priznanje kao odgovor za svoj doprinos i ostaće na njemu dok mu je omogućeno profesionalno dokazivanje, potvrda sopstvene vrednosti i dok tako postiže individualne $\mathrm{i}$ organizacione interese. Tip kreativnosti koja će biti zastupljena kod pojedinca (inovativna, produktivna, inventivna ili emergentna - vrhunska revolucionarna kreativnost), uslovljen je brojnim specifičnim osobinama, sposobnostima i svojstvima ličnosti, kao i karakteristikama samih poslovnih sistema i prirode posla u njima.

\section{INOVACIJE PUT DO NOVIH RADNIH MESTA}

Svaki poslovni sistem ima izgrađen sistem upravljanja ljudskim resursima. Bez obzira da li je taj sistem razvijen i sveobuhvatan ili nije, da li je funkcionalan ili nije, on je neodvojiv segment poslovnog sistema, jer on funkcioniše zahvaljujući svrsishodnom delovanju ljudi. Ta svrsishodnost $\mathrm{tj}$. ljudski rad mora biti oblikovan i omogućen, pokrenut i za njega moraju biti angažovani odgovarajući ljudi. To kako će menadžment ljudskih resursa biti organizovan na nivou svesadržajnom sistemskom prisustvu uprav- ljanja ovim ključnim resursom, zavisi od brojnih faktora. Suština upravljanja ljudskim resursima u rudarskim sistemima se odnosi na: ,upravljanje zapošljavanjem i razvojem ljudi“ i ,upravljanje angažovanjem ljudi““ kada su oni formalno već zaposleni.

Proizvodni razvoj rudarskih sistema je uslovljen stanjem ljudskog faktora proizvodnje. Sam nivo zaposlenosti u rudarskim preduzećima se pokazuje kao značajan činilac ekonomskog rasta ovih sistema. Pored nivoa zaposlenosti samog za sebe značajan činilac koji utiče na efikasnost i efektivnost rudarskih sistema je produktivna zaposlenost, kojom se prevazilazi neproduktivna zaposlenost, odnosno problem ekstenzivnog upravljanja.

Neproduktivna zaposlenost raste, a produktivna zaposlenost opada ako poslovni sistem zapošljava sve veći broj ljudi, iznad nivoa koji zahteva aktuelni obim njene proizvodnje. To se često događa zbog uvođenja novih teenologija i novih tehnoloških procedura u kojima visoko produktivne mašine, roboti i drugi automatizovani sistemi, zamenjuju veliki broj ranije zaposlenih ljudi, ali tako nastaje tehnološki višak koji ostaje formalno zaposlen u poslovnom sistemu. Sličnog karaktera je i višak zaposlenih koji nastaje racionalnijim organizovanjem rada, promenama proizvodno poslovne organizacije poslovnog sistema, kao i smanjivanjem fizičkog obima proizvodnje. Neproduktivna zaposlenost u našim uslovima često je nastajala i rasla zbog masovnog zapošljavanja motivisanog ne proizvodnim već socijalnim i političkim razlozima, (karakteristična je za osamdesete godine prošlog veka). Ekstenzivno zapošljavanje može nastati i kada poslovni sistem nije u situaciji da iz unutrašnjih izvora adekvatno regrutuje kandidate za upražnjena ili nova radna mesta pa je onda upućen na eksterne izvore. Ovakav oblik ekstenzivog zapošljavanja uslovljeno je ne samo subjektivnim uzrocima, već često i nedovoljnim 
mogućnostima angažovanja adekvatnih radnika sa jedne strane, a sa druge strane izbegavanjem ili smanjenim mogućnostima otpuštanja ili prekvalifikacije već postojećih zaposlenih. Ovde je problem u tome da struktura znanja zaposlenih $\mathrm{u}$ poslovnim sistemima, kao i onih koji su dostupni na tržištu rada, sve više zaostaje za potrebnom strukturom znanja. U ovakvim situacijama poslovni sistemi se nalaze u stanju neproduktivne zaposlenosti, a tržište rada u situaciji strukturne nezaposlenosti. Taj problem koliko god da je odlika našeg stanja osamdesetih godina prošlog veka on je prisutan $u$ nešto blažoj varijanti i danas, što je veliki problem. Ovo je inače problem u svetskim razmerama, koji je neravromerno izražen u različitim delovima sveta. Ključ razrešavanja ovog bitnog problema može se naći u dinamičnom restruktuiranju znanja kroz brojne oblike profesionalnog razvoja i treninge kako u poslovnim sistemima, tako i na tržištima rada, što i jeste njihova obaveza i zadatak. Problem svetske ekonomije, a naše u njoj, je u tome što su u posleratnim godinama nestale stotine različitih zanimanja, ustupajući mesto stotinama novih zanimanja koja nisu našla svoju adekvatnu primenu, a sve na štetu brojnih bazičnih zanimanja kao što su: rudari, metalci, građevinari i druga bazična zanimanja. Ovo ukazuje da je sve veći nesklad između proizvodnog i obrazovnog sistema. Reforme obrazovanja čak u mnogo razvijenim zemljama nisu dale očekivane rezultate, pa je nefleksibilnost obrazovanja delovala kao faktor usporavanja tehničko tehnološkog razvoja, što je slučaj i kod nas. U današnje vreme situacija je znatno bolja, ali ne i zadovoljavajuća. Velika brzina i stepen današnjeg razvoja nauke i novih tehnologija, kao i sve veća primena mikro procesora $\mathrm{i}$ biotehnologije, robotike i drugo u brojnim privrednim i neprivrednim delatnostima sve veći akcenat se stavlja na nefleksibilne obrazovne sisteme kako bi se adekvatno restruktuirali i obrazovali kvalitetne profile.
Ovakve situacije sve više upućuju na nove oblike $\mathrm{i}$ forme neformalnog obrazovanja i razvoja, kao i na samobrazovanje koje je poslednjih godina dobilo oblik permanenog procesa. Sistemsko obrazovanje i dopunsko osposobljavanje za nova zanimanja ostaje i dalje razvojni zadatak ultimativnog karaktera i u našoj zemlji.

\section{TRANZICIJA I ZAPOŠLJAVANJE}

Proces tranzicije u kome se nalazi Srbija, transformacija društvene svojine u drugačije svojinske oblike, uključivanje u svetske trgovinske tokove, strana ulaganja u domaću privredu i sve drugo zahteva korenitu promenu i stav prema ljudskim resursima, u načinu njihovog obrazovanja, razvoja, korišćenja i upravljanja. Putevi za podizanje produktivne zaposlenosti su različiti u različitim zemljama kao i različitim industrijama. Opšti trend zemalja u razvoju, gde se nalazi i naša zemlja, je privlačenje stranog kapitala, završetak tranzicionog procesa svojine, transformacija velikih poslovnih sistema u više malih i srednjih uz neodvojivi proces obrazovnog restruktuiranje znanja, sposobnosti i veština kako već zaposlenih tako i onih koji se obrazuju za zaposlenje.

Ubrzan privredni razvoj zahteva nova i savremena znanja koja moraju biti u skladu sa inovacijama iz okruženja jer je to jedini uslov, ne samo smanjenja gepa između razvijenih i nerazvijenih, već i opstanka na današnjem višesfernom globalnom tržištu. Zato se današnja globalna ekonomija naziva, "ekonomijom znanja", jer resurs sadržan u znanju postaje temelj proizvodnje i izvor bogatstva. Najveće mane u srpskom razvoju tiču se ljudskih resursa, a odnose se na neadekvatan sistem obrazovanja i nedovoljan razvoj zaposlenih kako na mikro tako i na makro planu, neadekvatnu brigu o ovom faktoru, kao i neadekvatno upravljanje ljudskim resursima. Tako stanje ključnog resursa osnov je nedovoljne konkurentnosti ovdašnje privrede, kao i jedan je od njenih 
dubokih, strukturno uslovljenih problema. Da bi se izašlo iz navedene situacije u kojoj se nalazi čitava srpska privreda uključujući i rudarsku proizvodnju, neophodno je čitav obrazovni i naučni sistem okrenuti prema proizvodnji i difuziji intenzivnih potrebnih nanja kao i fleksibilnom raspolaganju i korišćenju tih znanja i njihovom stalnom usavršavanju. Poslovni sistemi kao osnovni subjekti privređivanja treba da se razvijaju i da deluju na principima nove poslovne filozofije koja je uslovljena radikalnim promenama uloge i značaja ljudskog faktora u njima. Danas se sve više konstituišu sasvim novi organizacioni oblici, koji $u$ uslovima globalne privrede, na principima preduzetništva, obezbeđuju intenziviranje svih poslovnih resursa, a naročito ljudskih resursa, kao i efikasnije upravljanje i korišćenje istih radi većih poslovnih rezultata i veće konkurentnosti na tržištu.

\section{ZAKLJUČAK}

Promene su obeležje dvadeset prvog veka. One su duboke i brze, zahvataju sve oblasti delovanja i življenja. Promene u okruženju presudno utiču na oblikovanje budućih ciljeva privrednih subjekta, dajući im jedno novo obeležje i nov pristup, a to je strategijski pristup. Strategijski pristup predstavlja novi, modederan i nužan pristup upravljanja rudarskim sistemima, pod kojim se podrazumeva kontinualan proces prilagođavanja poslovnih sistema promen-ljivoj okolini. To dovodi do pojave strategijskog menadžmenta, a sa njime ljudski resursi postaju osnovni strateg i nosilac takvog upravljanja. Fokusiranje na ljudske resurse i na njihov razvoj poslovni sistemi postaju nosioci promena i stvaraoci sopstvene sudbine. Znanje kao rezultat razvoja zaposlenih, postalo je strateški resurs i izvorište konkurentne prednosti i diferencijacije u savremenoj ekonomiji. Investicije u znanje postaju najunosnija ulaganja $u$ društveni kapital i jedini put za izlazak iz ekonomske recesije u kojoj se nalazi srpska privreda i društvo. Samo nova i kvalitetna znanja i kreativnost ljudi mogu stvoriti novi posao, nova radna mesta, a time i nove procese i nove vrednosti čineći tako izvor bogastva i društvenog blagostanja. Trenutni nivo konkurentnosti srpske privrede i rudarskih preduzeća u njoj ne obezbeđuje osmišljeno međunarodno pozicioniranje. Za srpsku sveopštu situaciju, u kome se našlo celokupno društvo, nema lakog, niti brzog načina da ukloni barijere krupne determinante nekonkurentnosti. Na svim preprekama treba raditi intenzivno, studiozno, stručno, kvalitetno i domaćinski, uz pomoć inostrane akumulacije, za koju je nophodno stvoriti adekvatan privredni ambijent. Nov ambijent i novi društveni zakoni su infrastruktura za novo privredno delovanje, koje zahteva razvoj obrazovnog sistema i kvalitetnih ljudskih resursa preko velikih investicionih ulaganja u razvoj inovativnosti i novih privrednih subjekata s poštovanjem i uklapanjem u svetske standarde dobrog menadžmenta.

\section{LITERATURA}

[1] Grozdanić R.: Preduzetništvo, Fakultet Tehničkih nauka, Čačak, 2005.

[2] Senge P.: Peta Disciplina, Mozaik knjiga, Zagreb, 2001.

[3] Draker P.: Upravljanje u novom društvu, Adižes, Novi Sad, 2005.

[4] Draker P.: Inovacije i Preduzetništvo, Globus, Zagreb, 1992.

[5] Torrington D.: Menadžment ljudskih resursa, Data Status, Beograd, 2002.

[6] Janićijević N.: Organizaciono ponašanje, Data Status, Beograd, 2009.

[7] Ćamilović S., Vidojević V.: Osnove menadžmenta ljudskih resursa, Tekon, Beograd, 2007. 
[8] Bahtijarević-Šiber F.: Menadžment ljudskih potencijala, Zagreb, 1999.

[9] Radovanović V.: Menadžment ljudskih resursa, MST Gajić, Beograd, 2009.

[10] Radovanović V.: Organizaciono ponašanje, MST Gajić, Beograd, 2011.
[11] Stephen P. R.: Organizational Behavior, the second edition, prentice Hall, USA, 2003.

[12] Vujić D.: Menadžment ljudskih resursa i Kvalitet, Centar za primenjenu psihologiju, Beograd, 2003. 